\title{
Internet of things as a digital tool for the development of agricultural economy
}

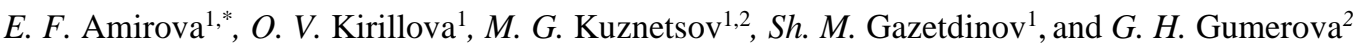 \\ ${ }^{1}$ Kazan State Agrarian University, Kazan 420015, Russia \\ ${ }^{2}$ Kazan National Research Technological University, Kazan 420015, Russia
}

\begin{abstract}
The article analyzes the research results of a number of analytical agencies regarding the growth rate and key problems associated with the introduction of the "Internet of things" (IoT) in the agricultural economy. The issues of the development of the agro-industrial complex in the context of the development of the digital economy, the experience of introducing the digital economy in the agricultural sector of developed countries and the possibilities of its application in agriculture in Russia are considered. The authors focuses on the positive aspects of the influence of the "Internet of things" on the functioning and development of modern agricultural markets at the macro and micro levels, and the change in the professional structure of the agricultural industry
\end{abstract}

\section{Introduction}

There are successful examples in foreign practice of introducing the "Internet of things" into the agroindustrial complex on the initiative of both the states [1] and business. For example, in the countries of the European Union, South Korea, China and India, "smart farming" technologies are being introduced having the ability to improve the efficiency of agricultural production. The Internet of Things is the second wave of a powerful digital revolution that began with the cosmopolitan diffusion of computers in the 1970s and 1980s. The Internet of Things provides consumers with new goods and services, and many of the existing goods and services become outdated.

Technology makes certain professions unnecessary, but at the same time leads to the emergence of new activities. The systems interconnected with the agricultural industry affect education, government and business, and make significant changes to the actions of people, their behavior and social norms [2].

New technologies affect absolutely all aspects of the development of the agricultural economy, from agricultural production to its sale to final consumers.

\section{Literature review}

In years ahead, the important changes are expected that will occur on Earth. According to the forecasts of demographic scientists, the population will overcome the 8 billion, which causes a natural need for innovation at all stages of the food chain. In the context of climate change and water shortages [3, 4], new technologies will provide the ever-increasing food needs of people. The most significant technologies designed to solve the global problem of food independence of Russia [5] and import substitution of agricultural products under sanction conditions $[6,8]$ :

1. "Digital twin". It is a digital analogue of a business modeling its arrangement. In agriculture, the "twin" will reflect all aspects from soil quality and tractor driver skills to the cost of melons sold on the market. The obtained data will help to predict yield. Thus banks will be able to give loans to farmers for business development, even if they do not have a credit history [8].

2. "Blockchain." Due to the Blockchain [9] and artificial intelligence [10], each participant in the supply chain will know exactly how many products need to be grown, ordered and shipped. As a result, food losses will be reduced and food will be fresher.

3. "Pathogen Sensors." Analysts expect that after 5 years, both food manufacturers and stores, and ordinary people will be able to detect pathogens in food using smart sensors. Devices will be either portable or built-in to countertops and mobile phones [11]. Mobile bacteria sensors will speed up pathogen tests from a few days to a few seconds.

4. "Micro-biome card file." Food safety inspectors will receive a methodology for quick analysis of microbial genetics. With its help, they will be able to learn about food safety, as well as use microbes to protect foods.

5. "Plastic preparation". All food packaging - from milk containers, cookie boxes, etc. - will be recycled.

Corresponding author: Elmira_amirova@mail.ru 
Fundamentally new ways of recycling old plastic will appear.

The ideology of the Internet of things is aimed at the improvement of the efficiency of the agrarian economy by automating processes in various fields of activity and excluding people from them [6].

A generalized diagram of the Internet of things network is presented in Figure 1.

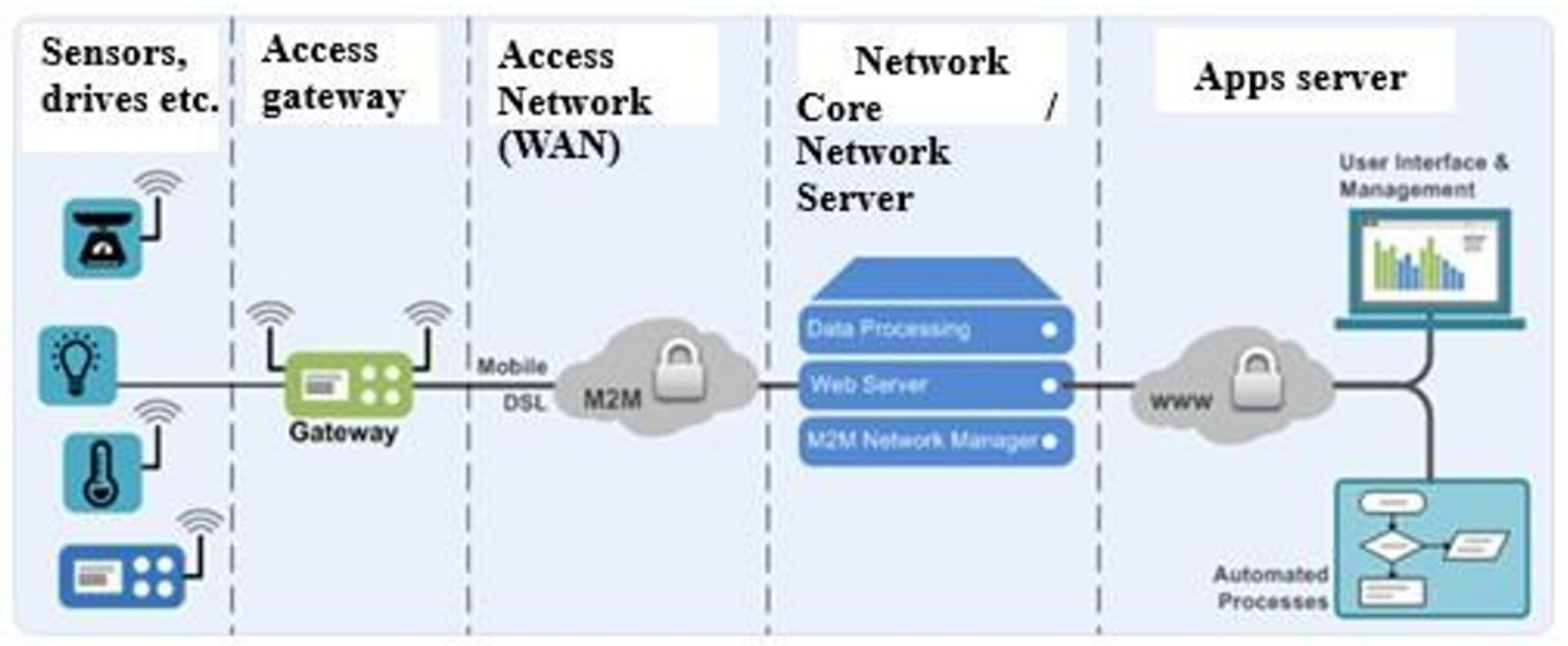

Fig. 1. Generalized scheme of the Internet of things network, which can be used in agricultural economy

The improvement of technological infrastructure and the use of huge databases of information caused a great digital transformation of our society [12].

If the last step of digitalization was based on the increase of Internet access for most consumers, the next step is distinguished by the integration of a wide range of digital services, goods and systems into the cyberphysical system. The mix of online and offline worlds proves the future of the digital economy.

It became possible with the help of some fundamental factors - the rapid spread of touch phones and huge databases of information. About 14 billion of mechanical devices, sensors are now using the Internet, and a double increase is expected by $2020.99 \%$ of world information is already on the World Wide Web and more than $50 \%$ has an IP address.

Despite numerous scientific publications and coverage of technologies related to the concept of the "Internet of things" by the media, this topic as a tool for the development of digital agricultural economy is not systematized and studied enough.

\section{Methodology}

During the research, standard testing methods were used that combined manual testing using automated tools. The devices and their components were evaluated on the basis of the specific vulnerabilities associated with each listed category. These studies were based on the analysis of the use of various devices of the Internet of things to increase the economic efficiency of agricultural production.

The solution to the problem of the development of models and algorithms of information interaction in the Internet of Things networks formulated in the article is based on methods of system analysis, probability theory, random processes and mathematical statistics, numerical analysis, and simulation.

\section{Strategies and prospects for the development of the internet of things technology}

If the platform concept is developed and implemented mainly in the segment of trade and logistics, then in agriculture the driver of digital development is the concept of Industry 4.0 and the smart factory as the technological core of Industry 4.0. All the elements of the "Smart factory" are extremely automated. The specific gravity and significance of R\&D in agricultural output is approaching the significance of $R \& D$ for complex technical products for individual orders [13].

The concept of the "Cyberphysical system" is close in meaning to the "Smart factory" technological concept of the "Cyberphysical system", understood as a single complex of computing resources and physical processes. Cyberphysical systems include sensors, equipment, and information systems, covering both individual agricultural enterprises and food complexes that implement sequential redistribution in value chains [14].

The use of Internet of Things technologies will change the face of agrarian industries, both taking into account the economic component and from the point of view of consumer experience. In agriculture, human labor and errors will be minimized.

\section{Results}

The great future of using the "Internet of things" technology for the development of agro-industrial production is opened by the latest technologies such as the widespread use of "chips". The specialists of San 
Diego Wireless Center designed printed metal tags chips that can be used to develop many agricultural subsectors. This technology is called LiveTag.

The invention lies in the fact that the labels attached to the objects of agricultural production will be able to transmit a signal over a Wi-Fi network, connecting the Internet of things technology. Thus LiveTag technology can be adapted to the hydration monitor by attaching it to a container of water and use the sensor to control the consumption of water by farm animals.

In addition it is assumed that LiveTag technology can be used to track human interactions with agricultural facilities. For example, LiveTag can potentially be used as an inexpensive way to assess soil moisture, the health status of farm animals and many other parameters of agricultural objects, control over which is necessary, but impossible without the use of modern technologies of the "Internet of things".

Another way to use the invention is labeling food products in retail stores in order to analyze big data about customer interests based and related products and their ultimate purchases for further optimization of the structure of the entire agro-industrial complex [15]. Instead of using cameras, stores can implement LiveTag as an alternative that offers customers more privacy. Within the framework of this research, it is impossible to demonstrate the full range of options for the functional use of the present invention. However, it is clear that there are a lot of them.

The IoT technologies in agriculture will increase labor productivity and competitiveness of the industry, given the growing demand for agricultural products. "Smart farms" and greenhouses will increase productivity (through the use of seeds, agrochemicals, fertilizers and water "on demand" and their more efficient use), improve product quality, reduce fuel consumption for agricultural machinery and water on farmland, reduce crop loss during storage and transportation [16].

The minimum economic effect of introducing the Internet of Things technology in agriculture can reach 469 billion rubles by 2025 . First of all, this will happen due to the saving of costs for maintenance and repair of production assets, increasing the energy efficiency of industries, buildings and structures; optimization of transport and logistics flows; increase the efficiency of production processes.

In agriculture, the IoT technology will enable the introduction of precise farming and significantly improve agricultural transport management. The key challenges for Russian farmers are the growth of national and international demand for agricultural products, as well as the need to increase labor productivity and competitiveness. However these challenges will inevitably be the driver of the industrial technological development [1].

In general, in the Russian Federation, taking into account both the general technological lag of the agricultural sector and the low level of labor productivity, the Internet of Things technologies are being introduced selectively and mainly by large players.
A number of major Russian players claim that the Internet of Things technology will make a breakthrough in the industry and enter a new level of competition. Smaller companies evaluate the impact of technology in a significantly limited format, seeing in it a tool to reduce production costs.

According to interviewed experts, the technology and monitoring techniques and precise farming technologies will have the greatest potential. In addition, the implementation of the Internet of Things technology will become a driver for the development of new related markets, such as the market for the production of unmanned aerial vehicles, drones, autonomous agricultural equipment, etc. [17].

\section{Discussion}

Analyzing the dynamics of the development of innovative technologies related to the concept of the "Internet of things" for the development of the agrarian economy of Russia, there is an increase in the "digital gap" (a gap in digital education, in terms of access to digital services and products, as a result, a gap in the level of welfare) within countries as well as between countries.

Nowadays, the digital economy is one of the priority areas of the Strategy for scientific and technological development of agricultural production in Russia. Full consistent digitalization of the Russian agricultural economy will become a platform for a qualitative change in its structure and long-term capabilities $[12,18]$. The Government of the Russian Federation is preparing a program "Digital Economy" for the intensive development of digitalization in Russia.

The program focuses not only on the basic components of digital economy, but also on the growth of private and public sector investments [19] in such promising areas as the Internet of Things, big data, and the development of IT products and services with high export potential.

This will increase the share of digital economy to $5.6 \%$ of GDP, as well as create large-scale intersectoral effects and real value added in the agricultural sectors up to 5-7 trillion rubles per year.

\section{Conclusion}

The technology of the "Internet of things" is not only technology, but also the basis of a new production system, a production philosophy for the development of the agro-industrial complex. Like any production system, the Internet of Things technology requires a significant transformation of methodologies, internal business processes, and the production and management culture of companies.

Therefore, the main task during the introduction of the Internet of Things technology into the agricultural economy is not so much the transition to new technology and IT solutions as the change in business models.

The technology of the "Internet of things" is recognized as priority in the development in terms of the 
potential for changing the business models of agricultural producers and the agro-industrial complex as a whole.

\section{References}

1. N.V. Zhahov, V.S. Krivoshlykov, M.V. Shatokhin, Ways of modern agri-culture in: specifics and state support in 30th Int. business information management association conf. - Vision 2020: sustainable economic development, innovation management, and global growth. IBIMA 2017 36463652 (2017)

2. E.A. Osadchy, E.M. Akhmetshin, E.F. Amirova, T.N. Bochkareva, Yu.Yu. Gazizyanova, A.V. Yumashev, Financial Statements of a Company as an Information Base for Decision-Making in a Transforming Economy European Research Studies J. 21(2), 339-350 (2018)

3. E. Yu. Ermakova, Yu. F. Korotkov, M. G. Kuznetsov, N. A. Nikolaev, Cleaning contaminated water by gravity flotation Chemical and Petroleum Engineering 46(1-2), 40-44 (May 2010)

4. N. F. Kashapov, M. M. Nafikov, M. X. Gazetdinov, M. M. Nafikova, A. R. Nigmatzyanov, Innovative production technology ethanol from sweet sorghum IOP Conf. Series: Materials Science and Engineering "Int. Scientific-Technical Conf. on Innovative Engineering Technologies, Equipment and Materials 2015, ISTC-IETEM 2015" 012012 (2016)

5. F. Nezhmetdinova et al., Global challenges for agrarian sector of Russian economy and it human resources Revista ESPACIOS 39(26) (2018)

6. O.V. Kirillova, Problems in the system of import substitution in Russia Bulletin of Kazan State Agrarian University 12 2(45), 120-123 (2017)

7. O.V. Kirillova, L.F. Sitdikova, D.I. Fayzrakhmanova, F.N. Mukhametdgaliev, Features of state support for the agricultural sector of the Russian economy and its role in supporting food security of the country Bulletin of Kazan State Agrarian University 10 2(36), 49-52 (2015)

8. S.N. Martyshenko, N.S. Martyshenko, Information technology for the construction of cognitive models Software systems and computational methods $\mathbf{4}$, 362-374 (2016)

9. O. Rostova, A. Dubgorn, S. Shirokova, A. Zabolotneva, A. Shmeleva, Features of using blockchain technology in healthcare in IEEE DSDT Conf. Proc. 53-57 (2018)

10. Sokolova, O. Leskina, E. Gubanova, O. Orlovtseva, T. Kanikhin, Application of artificial intelligence capabilities for practical needs of participants in economic processes in IEEE DSDT Conf. Proc. 155162 (2018)

11. N.S. Martyshenko, E.B. Kmet, A.G. Kim, A study of cell phone market in the Primorye territory (Russia) J. of Advanced Research in Law and Economics 7(8), 2132-2142 (2016)

12. T.A. Khudyakova, A.V. Shmidt, Methodical approaches to managing the sustainability of enterprises in a variable economy Espacios 39(13), 28 (2018)

13. N. F. Kashapov, M. M. Nafikov, M. Kh. Gazetdinov, Sh. M. Gazetdinov, A. R. Nigmatzyanov, About one approach to the assessment of technical equipment of agricultural enterprises in conditions of economy modernization IOP Conf. Series: Materials Science and Engineering 412, 012038 (2018)

14. E. F. Amirova, L. I. Petrova, E. V. Ziuzya, V. V. Sleptsov, T. I. Krishtaleva, M. V. Kuznetsova, Import substitution as an economic incentive mechanism for Russian commodity producers Int. J. of Civil Engineering and Technology 10(2), 926931 (2019)

15. M.Kh. Gazetdinov, R.M. Gilfanov, Sh.M. Gazetdinov, O.S. Semicheva, Modeling the production structure of small and medium-sized enterprises in the agricultural sector of the economy Bulletin of Kazan State Agrarian University 12 2(44), 98-102 (2017)

16. T.A. Khudyakova, A.V. Shmidt, Improving the efficiency of the enterprise's activity based on the implementation of the controlling system in Proc. of the 12th Int. Conf. on Strategic Management and its Support by Information Systems 46-52 (2017)

17. E. F. Amirova, O. Y. Voronkova, K. A. Pyurveeva, M. A. Shatalov, T. A. Panteleeva, O. A. Sorokina, Functioning of agroindustrial complex in the conditions of digital economy Int. J. of Mechanical Engineering and Technology 9(12), 586-594 (2018)

18. T.A. Khudyakova, A.V. Shmidt, Uncertainty of external environment during the construction of the controlling system of sustainability in Proc. of the 26th Int. Business Information Management Association Conf. - Innovation Management and Sustainable Economic Competitive Advantage: From Regional Development to Global Growth, IBIMA 2015 1607-1611 (2015)

19. F.F. Gatina, A.R. Artamonicheva, Features and criteria for attracting investment in the Russian economy Bulletin of Kazan State Agrarian University 3 2(8), 13-15 (2008) 